TH.J. G. LOCHER

\title{
RÜTER, THE HISTORIAN
}

The unexpected death of Adolf Johann Cord Rüter on August I I, 1965 , has deeply affected his colleagues and co-workers, his students and his friends. But if for them all his decease was a grievous personal loss, for his country it was more; both the pursuit and the teaching of history have suffered inestimably through his passing. In the following pages an attempt will be made to give a brief outline of Rüter's work as a historian and a professor of history, an account of his activities as director of the International Institute of Social History in Amsterdam being left to a more competent hand.

Rüter was one of the first and foremost protagonists of the study of social history in the Netherlands, a pioneer in a field not very much cultivated before him. He did not, however, become a specialist in the narrow sense of the word, and was always aware that social history was an aspect, or part, of history as a whole. His main works - the one on the great railway strike of 1903,1 and the other on the railway strike of $1944-1945^{2}$ in the Netherlands - give testimony to this kind of approach, each of them describing an important event in the social history of his country, framed in the larger setting of the political and economic history of the period.

Rüter's predilection for social history was not inherited from those under whom he read history at the Leiden University during the years 1926-1931: Huizinga, in his books and courses on the history of civilization, gave little attention to social questions, and Colenbrander's principal interest lay in political and constitutional history. Not that Rüter excluded cultural, let alone political, history from his sphere of interest. When reading history as a student his major subject was mediaeval history and he even wrote a paper on St. Augustine. His inaugural address as a professor of Dutch history in Leiden, given in 1946 , was devoted to a theme taken from the history of political

1 De spoorwegstakingen van 1903; een spiegel der arbeidersbeweging in Nederland, Leiden I935. 600 pp.

2 Rijden en staken; de Nederlandse spoorwegen in oorlogstijd. With an English summary, 's-Gravenhage I $960.478 \mathrm{pp}$. 
ideas: Past and Future as Sources of political Inspiration. ${ }^{1}$ His courses ranged widely, including, for example, the history and problems of the Dutch Revolt in the I 6 th century, the foreign policy of the Republic of the United Netherlands, the origins and development of historiography in the Netherlands. Latterly he had been working on a study of the great Dutch nineteenth-century historian Robert Fruin, who was by no means a specialist in social history.

His life's work, nevertheless, was in social history. At the root of this preoccupation there surely lay a feeling for the "underdog", although as far as is known he never explicitly gave expression to it. He was not, for that matter, a man to give vent to his feelings at all.

His first great work in the field of social history was his doctoral thesis, a masterpiece, by any professional standard, from one then only 28 years old. The great railway strike of 1903 , a test-case of the maturity and vigour of the labour movement in this country, was the subject, but the subtitle indicates the broad framework in which the events of 1903 were set: A Mirror of the Working-class Movement in the Netherlands. ${ }^{2}$ This movement had a late start here, in contrast with England for instance, on account of the late development of modern capitalism in Holland. A few years after, Rüter was to write the more detailed story of the early labour movement in Holland, ${ }^{3}$ but in his doctoral thesis he had already sketched the main line of development: a modest and rather timid beginning, under the patronage of liberal, or "Christian" politicians, without ideas or intentions of class struggle; then, with socialism gaining ground, in the socialist branch of the movement a tendency towards chiliastic expectations, centered around the messianic leader Domela Nieuwenhuis who started as a marxist but later on more and more turned towards anarchism. After the inevitable disenchantment there followed a period of hesitation and division of opinions as to the tactical methods, but also of intensification and growing militancy leading up to the dockworkers' and railwaymen's strike of 1903, struck down by the government of Abraham Kuyper through an act of parliament forbidding employees in government or semi-public services to use strike action as a weapon in their struggle. The general strike called by the socialists against this so called "strangling act" ended in failure.

1 Verleden en toekomst als bron van politieke inspiratie. Rede uitgesproken bij de aanvaarding van het ambt van hoogleraar in de vaderlandsche geschiedenis te Leiden op 31 mei 1946, Haarlem 1946. 31 pp.

- See p. 360 , note I.

- Hoofdtrekken der Nederlandsche arbeidersbeweging in de jaren 1876 tot 1886 , in: International Review for Social History edited by the International Institute for Social History, Amsterdam, Vol. III (1938), pp. 107-1 84, and Vol. IV (1939), pp. 171-230. 
After this, the socialist labour movement proved to have learned its lesson, dropped its utopian illusions and chose the road of realism. Rüter gave a picture of these events, full of details and yet drawn in sharp lines, clearly set against the backgrounds of the political structure and the economic conditions of the time, and written in a vigorous style. History, in this particular case, was "a young man's game".

During these years, Rüter for some time taught history and Dutch language in a grammar school, but soon he received an appointment in the International Institute of Social History, founded by the late Professor N. W. Posthumus, whom he was to succeed as director in 1953. Soon after the German occupation he had to leave the Institute and acted as an employee, in the end as deputy librarian of the Utrecht University Library. At Utrecht, he took up another task: the editing of the reports of the Dutch provincial governors regularly sent to the King of the Netherlands from I 840 until I 849. Rüter's death has left the work incomplete: three volumes have been published, covering the period up to the year $1845^{1}$. By unearthing the raw materials his aim was, as he himself states, "to contribute to the knowledge of the growth of the Dutch people towards their coming of age".2 So, in his eyes, it was again a work of social history in the sense he many years later employed it: "the history of estates, classes, social groupings regardless of name, seen both as separate and as mutually dependant units". ${ }^{3}$ This is a broader conception than the traditional continental meaning of social history as the history of labour and the working class. It is in this broader sense that Rüter wrote the programme for the International Review of Social History, edited since 1956 by him and members of the staff of the Institute. ${ }^{4}$ Rüter's social history involved the portrayal of the character of the Dutch nation, as was done in his booklet "The Dutch Nation and the Dutch National Character" (1945), ${ }^{5}$ an elaboration of lectures given during the time of the German occupation, when reflection on the values of our national character was deepened. In spirit Rüter showed himself a pupil of Huizinga, who repeatedly wrote on the same subject, though he does, of course, give more room to the class element in the Dutch national structure.

1 Rapporten van de gouverneurs in de provinciën I840-1849, I, Periodieke rapporten I840-1842; II, Periodieke rapporten I843; III, Periodieke rapporten I844, I845. In: Werken uitgegeven door het Historisch Genootschap (gevestigd te Utrecht), Derde serie, nrs. 73 (1941), 77 (1949) and 78 (1950).

- Rapporten etc., Vol. I, p. VI.

- International Review of Social History, Vol. I (1956), p. 4.

- Introduction, International Review of Social History, I, pp. I-7.

- De Nederlandse natie en het Nederlandse volkskarakter, Utrecht I945. $4^{8}$ Pp. 
In an article published in $194^{1}$ he gave full attention to the Dutch characteristics of the Netherlands' labour movement. Two years later, in 1948 , he contributed a larger treatise to a volume commemorating the centenary of the Netherlands constitution of 1848 , entitled "The Constitution and the Dutch Character". ${ }^{2}$ Here the spirit, of both Huizinga and Colenbrander, is present, even in the style. It is certain, though, that with all his admiration for Huizinga, Rüter felt a closer affinity with Colenbrander, on whom he wrote a necrology (1947) ${ }^{3}$ giving a portrait which, in some respects, has a striking resemblance to his own character.

Nothing can show better Rüter's character, in particular his stalwart probity in matters of professional ethics, than the story of his second magnum opus, viz. the history of the railway strike in the last year of the German occupation 1944-1945. The similarity of the two strikes, of 1903 and of 1944 , is rather superficial. The railway strike of 1944 was not an action of the railway-workers for higher wages or better social conditions; it was ordered by the Netherlands government in exile (London) in accordance with the Allied Headquarters, as a move in the battle of Arnhem against Nazi Germany. In his research, Rüter soon became aware that, in order to give a well balanced evaluation of the actions of the people involved (railway directors and employees), it was necessary to take into consideration their attitude from the beginning of the German occupation in 1940. So the book was given the title: "Riding and Striking; the Netherlands Railways in Wartime"." Every historian knows the difficulties of writing contemporary history, but in addition to these, Rüter was especially handicapped by the fact that in Dutch public opinion the railway strike had taken shape as a heroic exploit, and that its story had been virtually canonized. Rüter could not but state that the railwaymen, like so many other people in civil or public service during the war, had had to compromise with the German authorities in order to keep things going. The railwaymen had to keep the trains moving for the sake of the national economy. Resistance was offered against exorbitant demands from the German side, but many regrettable things were done, and trains run by Dutch engine drivers and guards had trans-

1 De Nederlandse trekken der Nederlandse arbeidersbeweging, in: Nederland tussen de natiën; een bijdrage tot onze cultuurgeschiedenis onder redactie van dr. J. S. Bartstra en prof. dr. W. Banning, I, Amsterdam 1946, pp. I 84-2I 2.

2 De grondwet en het Nederlandse volkskarakter, in: Grondwet en maatschappij in Nederland I 848-1948, edited by prof. mr. J. Valkhof, Den Haag 1948, pp. 266-326.

3 Herdenking van H. T. Colenbrander ( 13 December $1871-8$ October 1945), in: Jaarboek der Koninklijke Akademie van Wetenschappen 1947-1948. 10 pp.

- See p. 360 , note 2. 
ported Jews and victims of the German forced labour requisitions to Germany. So Rüter's history was not an epic of superhuman heroism, but the story of men who in very difficult circumstances did their utmost to spare as many interests as they could.

Since the book was written at the request of the Netherlands State Institute for War Documentation and before publication had to be submitted to the Directors of the (semi-public) Netherlands Railways, the latter insisted that the author should make alterations. This was a request he could not possibly comply with as an honest historian. The conflict lasted five years and in the end Rüter won the day. One can only guess how much stress this must have cost him, on top of his none too easy and increasingly lonely private life, since he was not the man ever to complain.

Rüter the historian was also Rüter the teacher of history. He was professor of Dutch history at the University of Leiden from 1946 until 1961, in which year he filled the new chair of social history. Needless to say, despite all his other activities he was devoted to his educational task, but there is more: he took a warm-hearted interest in the fortunes of his students and, though a pithy examiner, his judgment was humane. Small wonder then that the number of students taking social history as a major or minor subject was on the increase, particularly during the last years of his life.

Nor should we forget Rüter the administrator. His sense of social responsibility moved him to accept tasks and duties on faculty and university boards, and for long years he acted as secretary of the Netherlands Committee of Historical Sciences. In this capacity he was the organizer of many congresses of Dutch historians and also one of the chief "liaison-officers" with the International Committee of Historical Sciences. ${ }^{1}$

Rüter the historian will long be remembered as a prominent scholar, a conscientious and warm-hearted teacher and educator, and an able organizer, a brilliant and fearless man whom we shall miss in many places.

1 At the Ninth Congress of the International Committee Rüter presented a teport on modern social history, published in IXe Congrès International des Sciences Historiques, I, Rapports, Paris 1950, pp. 296-304. 